\title{
As Categorias de Aristóteles e a doutrina dos traços do ser
}

\author{
Marco Zingano \\ mzingano@usp.br \\ Universidade Estadual de São Paulo (USP), São Paulo, Brasil
}

resumo Neste artigo, propõe-se uma leitura das categorias no tratado aristotélico homônimo como um primeiro esboço de uma ontologia regional, centrada nas substâncias sensíveis. Tendo por foco substância, quantidade, qualidade, relativo, agir e sofrer, este trabalho busca expor as duas estratégias principais que Aristóteles parece empregar para chegar a uma lista das categorias: (a) características básicas, cuja satisfação ou não satisfação de cada uma determina a natureza categorial de cada item e (b) a propriedade única que caracteriza cada categoria em contraste com todas as outras. São, então, feitas considerações para vincular esse primeiro esboço ontológico a temas discutidos nos livros Lambda e Zeta da Metafísica, de modo a sugerir as direções principais que a sua ontologia nova (e geral) seguirá ao evoluir para uma teoria unificada da substância.

palavras-chave Metafísica; Categorias; Ontologia regional; Aristóteles; Ser; Substância

O tratado das Categorias tem uma posição ímpar na transmissão das obras de Aristóteles, assim como na interpretação de seu pensamento. Na famosa edição de Andrônico, que serve ainda hoje de base à ordem dos tratados no corpus aristotelicum, o tratado figurava no início do Organon, dando início, deste modo, às obras de Aristóteles. A sua posição, bem como o título respondem já a uma certa interpretação, o que certamente pode ser discutido ${ }^{1}$; porém, o fato é que, posto nesta posição privilegiada, o tratado ganhou especial destaque na leitura de Aristóteles já pelo simples fato de quem quer que quisesse ler as obras de Aristóteles era por isso mesmo fortemente convidado a começar pelo começo - neste caso, pelo nosso tratado das Categorias.

Recebido em 30 de maio de 2013. Aceito em 01 de julho de 2013.

doispontos, Curitiba, São Carlos, vol. 10, n. 2, p.225-254, outubro, 2013 
Não se trata, contudo, de uma mera vantagem de localização no corpus; desde cedo, o tratado foi considerado como inaugurando o estudo da filosofia aristotélica: é assim, pois, como Porfírio o apresenta. ${ }^{2}$ Porfirio segue a lição plotiniana, que via na análise aristotélica das categorias (realizada neste tratado) a base do estudo a ser feito a respeito do ser das substâncias sensíveis, ele próprio um estudo prévio que deveria ser seguido pelo estudo dos cinco grandes gêneros platônicos aplicados ao inteligível, perfazendo assim as etapas necessárias para o estudo do ser. ${ }^{3}$ Introdução, mas não introdutório: o próprio Porfírio redigiu uma Eisagôgê ("Introdução") aos textos de Aristóteles, pois considerou que, "mesmo para o ensino das categorias de Aristóteles” (Eis. 1, 3-4) ${ }^{4}$, faz-se necessária uma introdução às noções de gênero, diferença, espécie, próprio e acidente. ${ }^{5}$ Esboça-se assim o programa dos estudos filosóficos estabelecido pelos neoplatônicos, que se constituirá como que em uma cartilha que ganhou certa rigidez em torno do séc. V: o iniciante, quando chegava propriamente à matéria filosófica, começava por uma introdução geral à filosofia e passava por uma introdução especial à Eisagôgê para ser finalmente introduzido à própria Eisagôgê, à qual se seguia o estudo das Categorias, o que enfim the abria as portas ao estudo da filosofia de Aristóteles - por sua vez meramente a parte preliminar do verdadeiro tema, a filosofia platônica. ${ }^{6}$

$\mathrm{O}$ tratado das Categorias, porém, não deixou de provocar discussões e controvérsias. Uma delas diz já respeito àquilo a que se refere o título - tomando por título da obra o que nos foi tradicionalmente legado, a saber, Categorias. A discussão pode ser rastreada já na Antiguidade (quando se desenvolve em torno do título da obra e do sentido a atribuir a катпүоріа), mas ganhou maior impacto no grande momento da filologia moderna alemã. No século XIX, Adolph Trendelenburg sustentou que катпүпрía tinha o sentido básico de predicado, ou melhor: predicação. ${ }^{7} \mathrm{Na}$

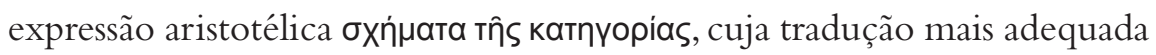


figura, e não propriamente a катпүорía, que é vertido mais precisamente por predicação. ${ }^{8}$ As categorias exprimiriam assim os tipos básicos de predicação, estando deste modo comandadas pela estrutura sintática da língua. Esta interpretação realça a ligação de katnyopia, alçado por este tratado a termo técnico filosófico, com o uso corrente na língua grega de katnүoคعîv: acusar, atribuir, imputar e daí, generalizando, predicar. No século XX, em 
terras francesas, Emile Benveniste tentou mesmo calcar a tabela aristotélica das dez predicações nas estruturas sintáticas de base a título de categorias linguísticas como que oferecidas inconscientemente a Aristóteles por uma língua particular, o grego antigo. ${ }^{9}$ De modo menos radical e mais cauteloso, mas em direção semelhante à destes autores, Pierre Aubenque também as examinará pelo ângulo de seu enraizamento na língua e nas formas gerais de predicação. ${ }^{10}$

Em contraste, Hermann Bonitz sustentou que o termo кaтnүopia designava antes os diferentes modos - tomados em sua máxima generalidade - pelos quais asserimos o ser. Bonitz procurava enfraquecer a ligação com a noção sintática de predicado, fortalecendo, ao contrário, a associação com a noção de gêneros supremos do ser. Neste sentido, ele nega que a tábua de categorias derive de relações sintáticas ou gramaticais, como se refletissem as estruturas básicas da predicação; as categorias são antes os conceitos supremos que são designados pelo nome comum de ser, tò öv, e por isso designam mais propriamente "os gêneros supremos do ser". ${ }^{11}$ Franz Brentano, em sua tese doutoral sobre os diversos sentidos do ser em Aristóteles, adotou a posição de Bonitz. ${ }^{12}$ É esta também a posição que Eduard Zeller assumiu em sua muita influente obra Die Philosophie der Griechen in ihrer geschichtlichen Entwicklung, que marcará gerações de leitores desde sua primeira edição em 1844, aumentada e corrigida em sucessivas edições e traduzida para diversas línguas. ${ }^{13}$

Há outras questões que também provocaram discussões. Limitandome ao problema das categorias, uma delas diz respeito ao número das categorias. Este número é por certo determinado (cf. An. Post. I 22 83b15), mas há flutuação sobre qual é exatamente este número. Nas Categorias e nos Tópicos, Aristóteles apresentou a lista mais abrangente, contendo dez categorias, mas, nos Segundos Analíticos I 22, somente oito são listadas (as


ainda outra redução, tendo agora sete membros, pois lá Aristóteles escreve

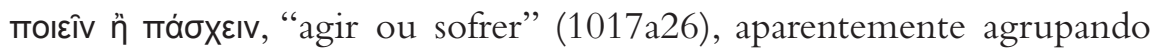
estas duas categorias em um só tipo. Em K 12 1068a8-9, a categoria do пои́ (onde) deixa de ser listada, havendo então somente seis categorias. Em Z 4 1029b24-25, ela volta a ser mencionada, mas o relativo, o estar em uma posição, o ter, o agir e o sofrer são postos sob a rubrica geral de kivnбıs, movimento, resultando em um número de seis categorias. Poder-se-ia 
pensar que a solução estaria apresentada em E 2 1026a36-b1, quando são mencionadas as mesmas categorias de $\mathrm{Z} 4$, mas, no lugar de kivnбıs, aparece a expressão mais vaga "e alguma outra, se houver", deixando assim em aberto o número exato, bem como sua(s) nomenclatura(s). Porém, a lição a reter é que, ainda que o número das categorias seja determinado, Aristóteles mostra-se disposto a revisar sua lista, preservando, porém, algumas categorias em todas elas.

Um problema mais premente, porém, tomou conta das discussões mais recentes. O tratado das Categorias apresenta uma série de anomalias, o que gerou a questão acerca de sua autenticidade e composição. Há, de um lado, problemas internos. $\mathrm{O}$ tratado começa de modo abrupto, sem introdução, sem indicação do tema ou da metodologia a ser seguida, como é costumeiro nos escritos certificadamente aristotélicos. Ele não faz nenhuma referência a outros tratados, assim como não é referido por nenhum outro - o que também é singular, sobretudo porque a doutrina das categorias é um tema frequentemente referido nos outros tratados. ${ }^{14} \mathrm{O}$ tratado está claramente dividido em três seções: (a) os ante-predicamentos (1a1 - b24); (b) os predicamentos $(1 \mathrm{~b} 25$ - 11b7) e (c) os pós-predicamentos (11b17 - 15b32). A seção que nos interessa aqui, a seção (b), é a maior, na qual são examinadas as categorias da substância, da quantidade, dos relativos, da qualidade e do agir e sofrer. Esta seção mostra certa relação com a seção (a) precedente. A seção (c) analisa noções não anunciadas previamente: a oposição, a contrariedade, a anterioridade, a simultaneidade e a mudança, se concluindo com um capítulo em que é examinada a categoria do ter (capítulo 15). ${ }^{15}$ Se compararmos com o que está ocorrendo no livro $\Delta$ da Metafísica, as noções examinadas na seção (c) não são surpreendentes; porém, entre as seções (b) e (c), há as linhas 11b10-17, claramente intercaladas por um editor no intuito de satisfazer a expectativa do leitor de encontrar as outras categorias também analisadas: a posição já teria sido analisada no capítulo consagrado aos relativos, ao passo que quando, onde e ter não precisam ser estudados porque são evidentes, segundo estas linhas claramente introduzidas para dar a impressão de unidade do tratado.

Estes problemas internos, porém, talvez não sejam os mais graves, pois há discrepâncias consideráveis com a doutrina da substância elaborada nos livros centrais da Metafísica. O tratado das Categorias chama de substância primeira o indivíduo e defende, a seu respeito, uma tese reducionista 
forte: tudo o mais ou bem está nele (os acidentes ou itens que inerem a um substrato) ou são ditos dele (as substâncias segundas, ou espécie e gênero). A posição do indivíduo continuará tendo destaque na Metafísica; no entanto, neste último tratado, não somente o indivíduo é analisado em termos de composto de matéria e forma (o que não ocorre nas Categorias), como a forma é alçada à posição de substância primeira, ao passo que o gênero é destituído de substancialidade (visto o destino do gênero, segundo $\mathrm{H}$ 1, estar ligado ao do universal, o qual é destituído de substancialidade em Z 13). Pode-se discutir sobre uma eventual continuidade entre um texto e outro, apelando em especial a diferentes pontos de vista da análise, mas certamente, pelo menos do ponto de vista da terminologia, há uma clara ruptura entre eles. Outros elementos aumentam a impressão que esta ruptura não é somente terminológica. Por três vezes, lê-se nas Categorias que as partes de um ser vivo são elas próprias substâncias (5 3a29-32; 7 8a16-21, 8b15-21); ora, Z 16 da Metafísica exclui definitivamente as partes dos seres vivos do rol das substâncias.

Em função destas e outras divergências, Suzanne Mansion tendia a atribuir o tratado das Categorias "à mão ainda inábil de um jovem discípulo de Aristóteles". ${ }^{16}$ Porém, em um artigo que fez data, Michael Frede defendeu a autenticidade do tratado. Tendo observado seus problemas internos de construção, mas também ressaltando sua proximidade terminológica com os Tópicos, bem como, conceitualmente, com o problema estabelecido nos diálogos médios de Platão a respeito dos universais e dos indivíduos que deles participam, Frede conclui colocando o tratado das Categorias, cuja doutrina seguramente difere, e consideravelmente das teses centrais da Metafísica, como um primeiro estágio de um longo desenvolvimento de reflexão que culminará na doutrina das formas substancias da Metafísica, um estágio no qual Aristóteles já invertia a relação platônica: no lugar de dar primazia ao universal, ele via no indivíduo a base ontológica do mundo. ${ }^{17}$

No que segue, vou defender também a autenticidade do tratado, na perspectiva de um estágio na formulação aristotélica do problema geral sobre a base ontológica do mundo. Concentrarei minha análise na parte central do tratado, a seção (b), e pretendo mostrar qual papel, penso, a reflexão a nós transmitida de modo provavelmente parcial pelo tratado das Categorias cumpre na constituição da metafisica aristotélica. 
Um primeiro elemento importante a ressaltar é a diferença significativa que vemos entre as duas listas de dez categorias que temos, a das Categorias e a dos Tópicos. Em Cat. 4 a primeira das expressões ditas sem combinação é a substância ou oủøıa. Esta categoria será imediatamente tratada no capítulo 5 e goza de uma posição privilegiada, pois indivíduos são substâncias primeiras, visto serem a base ontológica do mundo. Os


pıิ̂v: 103b20-1); porém, a primeira categoria é referida pela expressão ti


29, que esta categoria designa não somente as substâncias (entre as quais figuram primariamente os indivíduos, segundo o tratado das Categorias), mas toda e qualquer outra categoria, pois a respeito de cada uma sempre se pode fazer a questão “o que é?”. Pode-se, pois, perguntar do branco o que ele é, de um côvado o que é, e assim por diante.Tal como apresentada nos Tópicos, a primeira categoria remete à definição do item a respeito do qual se pergunta o que ele (essencialmente) é, mas esse item pode pertencer a qualquer categoria. Este problema vai reaparecer no livro $\mathrm{Z}$ da Metafísica, e de forma ainda mais radical, pois em Z 4-5 é investigado o problema de saber se há ou não definição das substâncias (agora vistas como, em primeira instância, as formas), das outras categorias, mas também de compostos acidentais como "homem branco". ${ }^{18}$ Z 4-5 apresenta duas respostas a esta pergunta. De um lado, há uma resposta restritiva: há definição (e portanto "quididade", tò ti ñv Eîvaı, pois a definição é a fórmula que exibe a quididade de algo) unicamente das substâncias; para os outros itens, há bem uma fórmula (入óyos, 4 1030a14) que diz que algo é predicado de algo ou que susbstitui o nome por uma expressão mais clara, "mas não haverá definição nem quididade destes itens" (4 1030a15-16). Por outro lado, há uma resposta mais branda: a definição e a quididade também se dizem em vários sentidos, de modo que, em sentido primeiro, há definição e quidade unicamente das substâncias, mas, em sentido derivado e secundário, há também definição e quididade para os outros itens, de modo que "haverá fórmula, isto é, definição também de homem branco, assim como, de outro modo, do branco e da substância" (4 1030b12-13; ver também 5 1031a11-14, que serve de conclusão a toda esta passagem). A resposta da Metafísica, para fixar a primazia da definição e da quididade à substância, precisa recorrer à noção de "um isto", тóঠદ TI, em um sentido 
bem especial, que infelizmente não posso examinar aqui, mas que certamente não se identifica mais imediatamente, como ocorria nas Categorias, aos indivíduos, pois permite agora uma paleta mais ampla de itens cuja estabilidade é suficiente para garantir a fixidez ontológica requerida por toda predicação.

Este, porém, é um problema que a Metafísica deve enfrentar; o tratado que nos interessa aqui, as Categorias, não se compromete com este ponto na medida em que toma a primeira categoria, aquela que serve de base para todas as outras, unicamente como substância, não introduzindo nela as outras categorias sob a forma da questão generalizada “o que é?", que se aplicaria então inevitavelmente a todas as predicações. ${ }^{19}$ Isso, porém, que parece ser uma posição de precaução é exatamente o que torna problemática a jogada conceitual das Categorias. Este ponto pode ser mais bem visto se compararmos o que o tratado das Categorias está fazendo com aquilo que Aristóteles faz no livro $\Delta$. Há um recobrimento em grande medida entre o livro $\Delta$, "o livro das múltiplas acepções" (Z 1 1028a11), e as seções (b) e (c) das Categorias. A seguinte tabela deixa isso bem claro (o sinal $\rightarrow$ indica que o mesmo tema é tratado):

Cat. 5 - substância $\rightarrow \Delta 8$

Cat. 6 - quantidade $\rightarrow \Delta 13$

Cat. 7 - relativo $\rightarrow \Delta 15$

Cat. 8 - qualidade $\rightarrow \Delta 14$ (8b27-9a13 $\rightarrow \Delta 19$ estado e $\Delta 20$ disposição; 9a28-10a10 $\rightarrow \Delta 21$ afecção)

Cat. 9 - agir e sofrer

Cat. 10 - opostos $\rightarrow \Delta 101018 \mathrm{a} 20-25$ (12a26-b25 $\rightarrow \Delta 22$ privação)

Cat. 11 - contrários $\rightarrow \Delta 101018 \mathrm{a} 25-38$

Cat. 12 - anterioridade $\rightarrow \Delta 11$

Cat. 13 - simultaneidade

Cat. 14 - mudança $\rightarrow \Delta 12$ (sobre potência)

Cat. $15-$ ter $\rightarrow \Delta 23$

Há, porém, muitas diferenças a considerar. Não há recobrimento perfeito; dois temas das Categorias não encontram correspondentes no livro $\Delta$; além da ordem diferir em um e outro, o livro $\Delta$ trata de outros temas que não são mencionados nas Categorias, cujo interesse filosófico está, porém, fora de dúvida (como princípio, causa, elemento, natureza, necessário e um, para citar somente os seis primeiros capítulos de $\Delta$ ). Quero, porém, 
chamar a atenção a um ponto preciso. Se olharmos lá onde há recobrimento, veremos que há uma diferença substancial no modo como os temas são examinados. Os capítulos da seção (b) das Categorias apresentam uma estrutura muito peculiar. ${ }^{20} \mathrm{Na}$ primeira parte de cada capítulo, os diversos sentidos e itens que a eles correspondem são listados; na segunda parte do capítulo, examinam-se quais são as características que um item deve possuir para figurar em uma das rubricas listadas na primeira parte. A este respeito, a diferença com $\Delta$ é muito grande, pois, em $\Delta$, os temas são tratados somente segundo a perspectiva (i), sem demonstrar nenhum interesse filosófico em detectar as características que permitem que um item figure em (i). Em suma, em $\Delta$, a parte (ii) está inteiramente enxugada; ela simplesmente desapareceu do horizonte de preocupação. O que, por sua vez, se desenvolve em $\Delta$ é que, na parte (i), são agora listadas não somente as acepções propriamente aristotélicas, mas também outras acepções, filosoficamente qualificadas, que podem, porém, apresentar-se como candidatos concorrentes à própria análise aristotélica. ${ }^{21}$

Fixemos a atenção na seção (b) do tratado das Categorias, a sua seção principal, com sua divisão de cada capítulo em duas partes distintas, a parte (i), na qual os diversos sentidos são listados, e a parte (ii), na qual são examinadas as características que um item deve possuir para figurar em (i). O seguinte esquema mostra como esta divisão está feita:

Cat. 5 - substância: itens (2a11-3a6); características (3a7-4b19)

Cat. 6 - quantidade: itens (4b20-5b10); características (5b11-6a35)

Cat. 7 - relativo:itens (6a36-b14;8a13-b21); características (6b15-8a12)

Cat. 8 - qualidade: itens (8b25-10a29); características (10a29-11a19)

Cat. 9 - agir e sofrer: itens (?); características (11b1-8)

Este quadro permite fazer as seguintes observações. Os capítulos da seção (b) organizam-se nestes dois momentos: (i) a lista do que faz parte da categoria em questão; (ii) o exame das características que todo item deve satisfazer para fazer parte da referida categoria. Para a categoria da substância, a parte (i) lista indivíduos, a título de substâncias primeiras, bem como espécies e gêneros, a título de substâncias segundas. Para a da qualidade, a parte (i) menciona quatro casos: o estado e disposição; a capacidade ou potência de algo; as qualidades afetivas ou afecções; e, finalmente, a figura e a forma exterior de cada coisa. Convém salientar que as listas em (i) podem sofrer alterações e acréscimos; assim, a respeito das 
qualidades, Aristóteles declara que "talvez algum outro tipo de qualidade se revele, mas os mais mencionados são basicamente estes" (10a25-26). Há, assim, não uma certa flutuação, mas o tratado não se quer peremptório; ele inaugura uma investigação, propõe uma classificação, mas está aberto a correções. O elemento de correção mais notável ocorre na categoria dos relativos. Inicialmente, é relativo todo item que for dito ser de algo ou que é de certo modo em relação a outra coisa. O problema é que esta definição parece ser generosa demais, pois a cabeça é cabeça de algo, a mão é a mão de algo e assim por diante. Como, nas Categorias, partes dos corpos são elas próprias substâncias, haveria aqui matéria de controvérsia para saber se substâncias são relativos. Substâncias primeiras não são por certo relativos, pois um homem não é de algo, tampouco uma certa mão é dita de algo, nem uma certa cabeça é dita de algo, segundo o argumento em 8a18-21. Porém, algumas substâncias parecem mesmo assim ser relativos - mais precisamente, as partes a título de substâncias segundas (pois, ainda que o homem não seja dito de algo, ocorre que a mão é dita de algo, a cabeça é de algo, e assim por diante: 8a26-28). Para evitar que substâncias e relativos coincidam, ainda que parcialmente (por conta das partes tomadas como substâncias segundas), a definição de relativo é tornada mais restritiva: é relativo aquilo que está em uma relação determinada com outra coisa, de tal modo que se segue como corolário que quem conhece um relativo, conhece por isso mesmo aquilo de que ele é relativo (8a28-37). Todo relativo é dito de algo, mas não é isso que o torna relativo, e sim o fato de estar em uma relação determinada com outra coisa, como o dobro em relação à metade. Ora, no caso das partes dos corpos, como a cabeça e a mão, é possível saber o que elas são sem saber de que elas são a cabeça ou a mão - por conseguinte, não são relativos, donde se pode dizer que "nenhuma substância é um relativo" (8b21).

Uma preocupação similar, a de evitar uma coincidência, ainda que parcial, com os relativos, também concerne às qualidades. O ponto é desenvolvido em 8 11a20-38 e pode ser resumido do seguinte modo. Entre as qualidades estão os estados e as disposições; ora, segundo o tratado das Categorias, a ciência é uma disposição (portanto, uma qualidade: 7

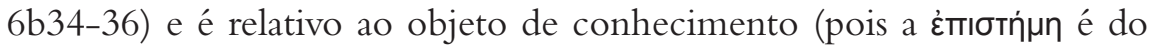
غ̇ாıбтпто́: 6b34-35) - e a este título é um relativo. ${ }^{22}$ Ora, uma confusão entre classes categoriais é certamente embaraçosa. A solução dada é que o 


\section{4}

conhecimento (a gramática, por exemplo) é de algo somente quando tomado genericamente, isto é, a gramática; quando falamos de uma gramática, a que Sócrates possui, por exemplo, ela não é mais dita de algo - ou pelo menos assim argumenta o autor das Categorias. Daqui é tirada a conclusão que as qualidades particulares não são relativos (11a32); ora, como é em virtudes destes particulares que somos qualificados, é isto o que importa, pois o caráter relativo dos termos genéricos é secundário. É feito assim apelo à tese geral, que permeia o inteiro tratado das Categorias, da primazia do particular ou individual sobre o universal ou genérico, o que permite desfazer aquela coincidência constrangedora, ainda que parcial, entre qualidades e relativos - pelo menos para efeito do que qualifica os indivíduos (visto que é na individualidade que reside a primazia ontológica).

É provavelmente esta anomalia que explica uma outra, a saber, que conhecimento e sensação, a título de relativos (tomados, portanto, como gêneros e não como particulares), não são simultâneos por natureza, ao passo que a maior parte dos relativos é simultânea por natureza, daí devendo decorrer que a eliminação de um acarreta a eliminação do outro. Ora, o objeto de conhecimento, assim como o objeto de sensação são anteriores, respectivamente, à ciência e à sensação; de mesmo modo, a eliminação da ciência ou da sensação não acarreta a destruição do objeto de ciência ou do objeto de sensação, respectivamente, embora a destruição dos objetos arraste consigo a destruição do conhecimento e da sensação. Esta anomalia encontra sua justificação na posição peculiar destas qualidades: enquanto particulares, não são relativos (e é esse o elemento fundamental na ontologia das Categorias); porém, a título genérico e universal, são relativos, pois o conhecimento em geral é dito de algo e a sensação em geral é dita de algo.

Uma consequência importante para o estabelecimento do texto parece também decorrer destas observações. Já foi notado que o capítulo 9, o último capítulo da seção (b), está truncado. Um modo de aliviar a estrutura do texto seria seguir a sugestão de Minio-Paluello, feita no aparato de sua edição crítica, de deslocar este capítulo, a saber, as linhas 11b1-8, para logo após a linha 11a14, que pertence ao capítulo anterior, sobre a qualidade, e que desenvolve o ponto de a qualidade admitir graus, o que seria uma de suas características. A sugestão foi acatada por Bodéüs, que assim transpõe estas linhas, eliminado o tradicional capítulo 9. Isso 
é possível, sem dúvida, mas não parece ser a melhor opção. Com efeito, pode-se supor, como também faz Minio-Paluello, que há uma lacuna, de tamanho desconhecido, entre o fim do capítulo 8 (linha 11a38) e a linha 11b1, que dá início ao que hoje temos como o capítulo 9 sobre o agir e sofrer. O que estaria ocupando esta lacuna seria, pelo menos, a parte (i) para a categoria do sofrer e agir (assim como, eventualmente, um desenvolvimento maior da parte (ii) sobre as características destas categorias). Esta suposição está baseada na estrutura da análise das outras categorias, cujos capítulos se articulam nestas duas partes (i) e (ii). Pode-se daqui também supor que a perda foi bem maior, incluindo os capítulos relativos às outras categorias - mas isso seria muito mais conjetural do que supor somente a perda da parte (i) do capítulo sobre o agir e o sofrer, cuja parte (ii) de fato possuímos.

Os problemas filosoficamente mais interessantes concentram-se na parte (ii) destes capítulos, contudo. $\mathrm{Na}$ parte (ii), a estratégia consiste em apresentar as características que todo item deve satisfazer para se qualificar como membro de uma das categorias. Vou denominar esta estratégia de uma doutrina dos traços do ser: um item qualquer, ao satisfazer tais e tais traços, será localizado em uma determinada categoria. Todo item deve ser localizado em uma categoria exclusivamente; por esta razão Aristóteles - ou o autor deste tratado - foi muito cuidadoso em evitar eventuais sobreposições entre as categorias na parte (i) de sua análise. Agora, na parte (ii), a ambição é de maior fôlego: trata-se de mapear a entidade em seus traços mínimos e classificar tudo o que é em dez tipos supremos de ser. O resultado é o seguinte:
(a) substância:
(i) não está em um substrato (3a7-32)
(ii) a predicação envolve sinonímia (3a33-b8)
(iii) é "um isto" (3b10-23)
(iv) não tem contrário (3b24-27)
(v) não admite graus (3b33-4a9)
(b) quantidade:
(i) não tem contrário (5b11-6a18; 3b28-32) [?]
(ii) não admite graus (6a19-25) 
(c) relativo:

(i) tem contrário $(6 \mathrm{~b} 15-19)\left[{ }^{\star}\right]$

(ii) admite graus $(6 \mathrm{~b} 19-27)\left[{ }^{\star}\right]$

(d) qualidade:

(i) enuncia-se de modo parônimo (10a27-b11)

(ii) tem contrário $(10 \mathrm{~b} 12-25)\left[{ }^{\star}\right]$

(iii) admite graus (10b26-11a14) [*]

(e) agir e sofrer:

(i) têm contrários (11b1-4)

(ii) admitem graus (11b4-8)

Este esquema traz imediatamente à mente quatro observações. Primeiramente, vê-se que é feito uso, na parte (ii) da seção (b), do que havia sido discutido na seção (a). Assim, a paronímia, que parece ter pouco uso na obra de Aristóteles, é expressamente referida como sendo uma característica das qualidades (assim como a distinção estar em - não estar em no caso das substâncias). Em mesma direção, os predicados das substâncias são ditos sinônimos, pois tudo o que é dito daquilo que é predicado também é dito do sujeito: o gênero, por exemplo, se predica da espécie e, portanto, do indivíduo do qual se predica a espécie. Esta regra será retomada na Metafísica sob a forma da transitividade dos predicados, propriedade com base na qual as predicações essenciais serão distinguidas das acidentais. Aqui, a referência a esta regra é feita nos termos estabelecidos no capítulo 1 das Categorias. Convém dizer que esta regra vale também para as diferenças específicas, pois aquilo que é dito delas é também dito do indivíduo de que se predicam.

Em segundo lugar, há lugar para controvérsias, o que foi indicado por [?]. Quanto às quantidades, é dito que elas não têm contrários: o dez não tem contrário, nem o dois, por exemplo, na matemática usada aqui dos números naturais. Poderia, contudo, parecer que possuam contrários, pois o muito teria como contrário o pouco; o grande, o pequeno, e assim por diante. Porém, neste caso, não estariam sendo tomados como quantidades, mas como relativos, o que isentaria a quantidade de ter contrário. Mais ainda: na verdade nem mesmo como relativos têm contrários, pois, embora haja relativos que tenham contrários, quantidades relativas não têm contrários 
(6b17-19), pois, se tivessem, a mesma coisa seria grande (em relação a X) e pequena (em relação a Y) - mas "é impossível uma coisa ser o contrário de si mesma" (6a7-8). Há por certo lugar para controvérsias, mas aquela que é mencionada é resolvida nos termos do próprio tratado.

Em terceiro lugar, deve-se observar que certos traços valem para alguns, ou mesmo para a maioria dos itens de uma categoria, mas não para todos - o que foi assinalado por ${ }^{[\star]}$. Nos relativos, há por certo contrários: por exemplo, a virtude é o contrário do vício, assim como o conhecimento é o contrário da ignorância. Porém, como acabamos de ver, alguns relativos não têm contrários, como o dobro, o triplo e todas as quantidades relativas. Havíamos também visto que ocorre aqui uma certa sobreposição entre qualidades (como virtude e conhecimento) e relativos (já que são de algo), porém essa sobreposição parcial era resolvida apelando à distinção central entre particular e universal: as qualidades particulares não são relativas, somente as genéricas o são, mas a entidade básica é garantida pelo particular, e somente daí se expande ao universal. Um problema similar ocorre com a admissão de graus por parte dos relativos, pois alguns aceitam graus, como o semelhante é dito mais ou menos semelhante, e todo semelhante é semelhante a algo (sendo portanto um relativo), mas, novamente, as quantidades relativas, como o dobro e o triplo, não admitem graus. ${ }^{23}$ Também as qualidades têm traços satisfeitos por uns membros, mas não por todos: o claro é contrário do escuro, mas não há contrário do amarelo, do azul e de casos similares. Igualmente, três casos de qualidade admitem graus (a disposição, a capacidade e a afecção), mas o quarto tipo - o formato exterior de algo - não parece admitir graus, pois "o triângulo e o quadrado não parecem admitir graus, nem nenhuma das outras figuras" (11a5-6). Assim, não há uma rigidez na aplicação destes traços, pois eles podem valer para todos, mas pode haver também exceções a eles.

A quarta observação nos levará a um segundo esquema. Deixando de lado os traços que provêm de uma aplicação à seção (b) do que tinha sido estabelecido na seção (a), os traços comuns limitam-se unicamente a dois: o ter contrário e o admitir graus. Estes dois traços, porém, não permitem distinguir os itens uns dos outros para assim os classificar exclusivamente em suas categorias respectivas. Substância e quantidade não admitem graus nem têm contrários, não se distinguindo assim uma da outra; relativo e qualidade admitem em parte graus e alguns têm contrários, 
distinguindo-se assim em bloco do agir e sofrer, pois todos os itens destes últimos admitem graus e têm contrários, mas não conseguem distinguir-se entre si. É provavelmente em função desta impossibilidade de distinguir exaustivamente todos os membros em questão que é proposto um segundo princípio de distinção, baseado agora não na satisfação ou não satisfação de um conjunto de traços, mas na presença de um traço distintivo ou próprio, que somente o membro de uma dada categoria satisfaz e que, satisfeito, torna tal item um membro de tal categoria. Estes traços próprios ou īōı são os seguintes:

(a) substância: pode receber contrários permanecendo um e mesmo item (4a10-b19)

(b) quantidade: ser dito igual ou não-igual (6a26-35)

(c) relativo: reciprocar $(6 \mathrm{~b} 28-7 \mathrm{~b} 14)$

(d) qualidade: ser semelhante ou dessemelhante (11a15-19)

(e) agir e sofrer: <lacuna?>

Este esquema é distinto do primeiro: no primeiro, tratava-se de estabelecer um conjunto de traços que, tomados coletivamente em sua satisfação ou não satisfação para cada traço, colocavam um item em determinada categoria; agora, trata-se de identificar um e um único traço, tomado como próprio de uma dada categoria, que, identificado em um item, o alça imediatamente a membro de tal categoria. Os dois esquemas estão justapostos. De fato, este segundo esquema é apresentado como fecho da parte (ii), em sequência à apresentação dos traços comuns. Assim ocorre no capítulo 5 (substância) e no capítulo 6 (quantidade). No capítulo 8 (qualidade), ele também conclui a análise dos traços, mas o capítulo como tal termina com uma observação sobre como distinguir as qualidades dos relativos, de modo a não confundir as duas categorias (11a20-38), o que não se enquadra nem na parte (i) nem na parte (ii) destes capítulos. Algo similar ocorre no capítulo 7 (relativo): a propriedade exclusiva aos relativos de reciprocar é apresentada em sequência à apresentação dos traços de ter contrário e admitir graus. A isso se segue uma discussão para mostrar que nenhuma substância é um relativo, nem mesmo as partes de um corpo tomadas a título de substâncias segundas, ainda que digamos que a cabeça é cabeça de algo (para sanar essa confusão, é introduzido um critério mais refinado de relativo em 8a31-33). Entre a apresentação do traço exclusivo e esta última discussão, intercala-se, contudo, uma passagem (7b15-8a12) 
sobre a simultaneidade natural entre os termos relativos, que ocorre na maioria dos casos, mas não em todos (pois a sensação e o conhecimento não são simultâneos em relação ao objeto de conhecimento e de sensação, respectivamente, nem a destruição dos primeiros acarreta a destruição dos últimos). Esta passagem parece ser uma decorrência ou corolário do fato dos correlativos reciprocarem. Se for isto, então se compreende por que sua análise é feita em sequência à apresentação do traço exclusivo dos relativos, a saber, o fato de reciprocarem: espera-se que termos que reciprocam sejam naturalmente simultâneos. ${ }^{24}$

Deve-se igualmente observar que esses traços próprios são introduzidos, no final da parte (ii), por meio de uma terminologia bem precisa: o traço próprio da substância é introduzido, no capítulo 5, por $\mu$ ádıฮтa $\delta \dot{\varepsilon}$ İळıov (4a11); no cap. 6, o traço próprio da quantidade é anunciado por


cap. 7 (relativo), a propriedade exclusiva não é introduzida por uma expressão deste tipo, mas deve ser inferida. Em 6b28-7b14 a reciprocação é apresentada como valendo necessariamente para todos os relativos, desde que os termos correlativos sejam corretamente fornecidos. Se é relativo, reciproca; como nenhuma relação, quando dada acidentalmente, reciproca (7a25-31), tem-se que, se reciproca, é relativo, o que garante a exclusividade da reciprocação para o relativo. Não é dito na passagem, contudo, que a reciprocação é o İठ̋ıv do relativo; o termo que mais se aproxima disso é oíkeia na linha 7a30; porém, que a reciprocação seja o próprio dos relativos pode ser inferido a partir do que é dito nesta passagem.

Temos, então, uma estrutura muito precisa dos capítulos:

(a) parte (i): lista dos casos;

(b) parte (iia): traços coletivamente tomados;

(c) parte (iib): traço próprio;

(d) resolução de eventuais conflitos entre itens de diferentes categorias.

Pode-se lamentar, do ponto de vista do conteúdo, que (b) não forneça uma resposta satisfatória, pois não foi apresentado um conjunto de traços suficientemente complexo, cuja satisfação ou não-satisfação de cada traço, tomando-os coletivamente, localizaria por si só um item em uma categoria de modo a excluí-lo de todas as outras. Igualmente, pode-se lamentar que (c), que vem em apoio a (b), termine de certo modo a se apresentar como concorrente de (b), pois (c) visa a identificar um traço 
próprio, ao passo que (b) tentava estabelecer um conjunto de traços que mapearia a inteira entidade segundo a situação de satisfação ou não-satisfação. Mesmo assim, não se pode não reconhecer que a arquitetura da seção (ii) é clara, muito bem construída e refletida. Sobretudo, o que é saliente nesta análise é que, por meio de uma doutrina dos traços - seja de uma satisfação ou não satisfação dos traços tomados coletivamente ou da satisfação de um traço exclusivo - Aristóteles (muito mais provavelmente do que qualquer outro autor) está buscando determinar os gêneros supremos do ser - exatamente aquela intuição que Bonitz teve ao ler as Categorias. Temos aqui um projeto metafisico bem delineado, ainda que se possa discutir sobre sua efetiva realização: determinar um conjunto de traços com vistas a estabelecer uma classificação exaustiva da entidade. Estes traços deveriam funcionar de modo semelhante à caracterização dos objetos naturais simples. Terra, água, ar e fogo satisfazem, cada um a seu modo, os pares de opostos seco - úmido e frio - quente; de modo similar (mas com óbvios limites nesta analogia), tudo o que é deve satisfazer, cada um segundo seu gênero supremo, um conjunto de traços que determinaria as suas condições gerais ou supremas de entidade.

Convém assinalar que tal projeto, ao se comprometer com uma classificação exaustiva da entidade, pode ser útil para diferentes áreas. Nas disputas dialéticas, por exemplo, é decisivo poder determinar com precisão aquilo de que se fala. Isso, por sua vez, muitas vezes coincide com classificar o item em sua correta categoria - afinal, se o item sobre o qual se fala estiver localizado em mais de uma categoria, ele estará sendo referido de modo homônimo, o que é uma causa corriqueira de desacordo entre os debatedores. Como observa Aristóteles no primeiro livro dos Tópicos, um dos instrumentos dialéticos consiste justamente em dissociar os diversos sentidos de um termo (Top. I 13 105a23-24) e, para tanto, uma das estratégias privilegiadas consiste em "verificar se os tipos de predicações em


em todos os casos, pois, se não o forem, é evidente que o termo em questão é um homônimo" (Top. I 15 107a3-5). Tem-se assim um bônus que este projeto metafisico fornece ao dialético (nos termos dos Tópicos): se for verificado que o termo em disputa está sendo predicado em diferentes categorias, mostra-se por isso mesmo que está sendo empregado de modo homônimo. Trata-se, porém, de um bônus: tal projeto de classificação 
exaustiva da entidade não é realizado com vistas a estas disputas, tampouco é subserviente ou restrito a elas. ${ }^{25}$ Sua ambição parece ser outra: mapear o ser em suas linhas mais gerais. A este título, tal mapa deve servir de guia às controvérsias filosóficas ou científicas. Com efeito, Aristóteles recorre ao expediente de determinar em que categoria um termo se diz ou deve ser dito também em seus procedimentos filosóficos ou científicos, ligados à busca da verdade e não simplesmente ao acordo entre opiniões. Ao constatar que o termo bem é empregado em diferentes categorias (de fato, em todas nas quais se dispersa igualmente ser), Aristóteles concluirá que bem não é dito de modo comum e universal (como supunha a tese platônica), pois, se fosse assim, "não seria dito em todas as categorias, mas em uma somente" (EN I 4 1096a28-29). Aristóteles está aqui argumentando em um contexto filosófico para descartar uma tese avançada (a tese platônica sobre o bem). Em linha similar, no De anima, ao iniciar o estudo da natureza da alma, Aristóteles preocupa-se preliminarmente em determinar em que categoria se encontra o objeto de estudo, a alma, "pois


-b1; cf. I 5 410a13-16). Após ter listado as posições de seus predecessores ao longo do livro I, Aristóteles dá início à sua própria teoria da alma no livro II, localizando-a de início e com clareza no primeiro gênero supremo, a substância, e isto a título de forma, preparando já o caminho para reconhecê-la como enteléqueia primeira (II 1 412a6-11).

O projeto do tratado das Categorias parece, assim, consistir em mapear a entidade segundo suas articulações mais gerais, os gêneros supremos do ser. Isso evidencia uma óbvia ambição metafísica, e de fôlego. No âmbito deste projeto, a parte (iia), os traços comuns, os que são tomados coletivamente em função da satisfação ou não satisfação de cada um deles, na medida em que está restrita àquelas duas características básicas, o ter contrário e o admitir graus, não consegue dividir exaustivamente a entidade em suas classes supremas. Porém, com a parte (iib), a que lista o traço próprio para cada categoria, o mapeamento ontológico parece ser bem sucedido - pelo menos no que tange às categorias examinadas. Há como distinguir substâncias, quantidades, relativos e qualidades uns dos outros - e a expectativa é que o mesmo procedimento pode ser aplicado às restantes categorias com igual sucesso. Pode-se então perguntar por que um projeto tão argutamente ambicioso e aparentemente bem sucedido 
ficou fragmentário e lacunar. Obviamente, parte da explicação reside nas condições precárias da transmissão dos textos de Aristóteles, que fez com que alguns textos portem lacunas e outros tenham simplesmente sido perdidos. Porém, isso não pode explicar tudo; pelo menos, não pode explicar por que não vemos maior impacto do próprio tratado das Categorias nas outras obras de Aristóteles, tendo sobretudo em vista que a questão das categorias do ser é omnipresente em sua obra. Como explicar não o estado lacunar, mas o silêncio sobre o próprio tratado?

Penso que um início de explicação filosófica a esta questão pode ser obtido se atentarmos ao traço que é próprio da primeira categoria, a substância. O que é próprio à substância é o ser capaz de receber contrá-

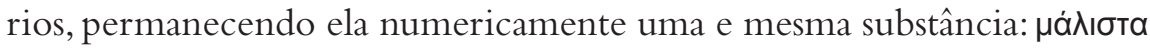

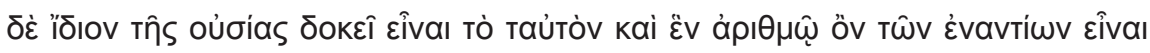
ठعктıкóv (5 4a10-11). A consequência disso é que a substância em questão aqui é a substância sensível, à exclusão de substâncias de outra natureza, pois a capacidade de receber contrários está condicionada às condições materiais de existência da substância, cuja matéria funciona como substrato para os contrários. Daqui se segue que o tratado das Categorias tem a ambição de traçar o mapa da entidade em seu domínio material ou sensível; trata-se, portanto, se posso me exprimir deste modo, da constituição de uma ontologia regional por meio de uma ontologia dos traços da substância sensível. Por si só isso não é um problema, pois não há eliminação, invalidação ou recusa de substâncias de outra natureza; simplesmente, estas últimas não entram no escopo da investigação, visto não poderem satisfazer a condição de receber contrários, já que esta condição requer um modo material de existir a título de substrato das diferentes afecções.

Uma situação ontológica similar encontra-se no livro $\wedge$ da Metafísica. Este livro pode ser dividido em três partes. Em uma curta introdução (1 1069a18-b2), Aristóteles apresenta os dois tipos de substância - a sensível e a não sensível, a primeira sendo subdividida em eterna e corruptível - e liga a cada uma a respectiva ciência, condicionando a independência entre estas ciências à eventualidade de não haver um princípio comum aos dois tipos de substância. ${ }^{26} \mathrm{Na}$ segunda parte (1 1069b3 - 5 1071b2), é feito o exame da substância sensível; a celebrada teologia de Aristóteles constitui o tema da terceira e última parte, na qual a natureza da substância não sensível é examinada a título de primeiro motor, pura atividade sem 
nenhum elemento material ou potencial (6 1071b3 - 10 1075a11). O que importa assinalar aqui é que uma parte considerável do esforço do livro consiste em mostrar que há um princípio comum entre os dois domínios: este princípio comum é o primeiro motor imóvel, que necessariamente é uma natureza outra que a substância sensível e sem o qual não é possível pensar a eternidade ordenada do movimento suposta no exame da substância sensível. O princípio é já mencionado na segunda parte, ao final do capítulo 4, de um modo algo abrupto, sob a forma daquilo que, a título

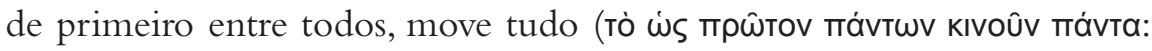
1070b34-35). Na terceira parte, ele é estudado a título de primeiro motor (ou motores primeiros, pois há uma pluralidade deles). Isso pode parecer tênue, mas é já forte o suficiente para evitar uma ontologia episódica, na qual cada nível possuiria seus próprios princípios, um nível não tendo impacto sobre o outro. Aristóteles refere-se de modo fortemente pejorativo a este episodismo do ser ao final de $\Lambda$, em 10 1076a1-2, e, pelo que podemos reconstruir com a ajuda de Z 2 1028b21-24 e N 3 1090b13-20, ele está criticando duramente a posição de Espeusipo. ${ }^{27}$

Com efeito, contrariamente ao que postulava Espeusipo, há bem uma relação ou conexão principial entre as duas esferas ou domínios. A Metafísica de Teofrasto parece ser um texto que retrata um mesmo ambiente conceitual, estando assim muito próxima do livro $\wedge$. Nela, Teofrasto escreve que a investigação metafisica se inicia com a questão de saber se existe uma certa conexão e uma comunidade de algum tipo entre os dois domínios, o da substância sensível e o da substância não sensível, ou se não há nenhuma, ainda que uns e outros acabem por convergir, de certo modo, em uma única totalidade por estarem simplesmente justapostos. Teofrasto pergunta-se,

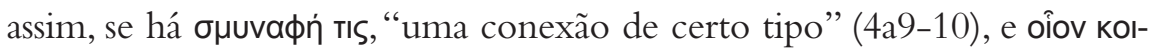
vwvía, "como que uma comunidade" (4a10), onde tis e oîov enfraquecem ao máximo essa união, ao mesmo tempo em que apontam a algum tipo de ligação, não permitindo que haja uma desconexão total entre os dois domínios. Em particular, tis tem aqui muito provavelmente o valor alienans: não é exata ou propriamente uma conexão, pelo menos não no sentido forte, pois não satisfaz todos os requerimentos para tanto, mas é ainda assim um certo tipo de conexão, algo que faz as vezes de uma ligação. A esta questão, assim formulada, entre um todo desconectado, sem que uma parte dependa ou colabore com a outra, ainda que acabem por conviver em uma dada 


\section{4}



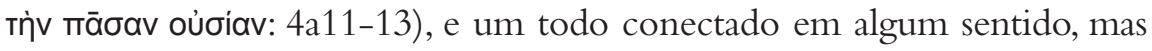
não perfeitamente ligado, em todo caso certamente não derivado de uma fonte única, Teofrasto se apressa a responder que a solução mais plausível

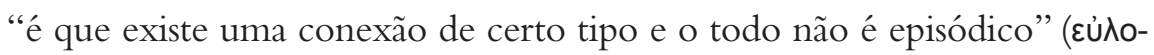

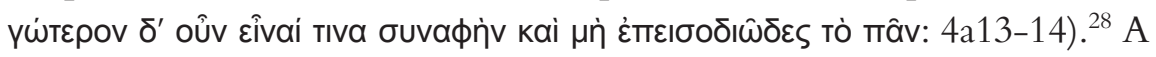
resposta, novamente, se dirige ao reconhecimento de alguma conexão, descartando a versão espeusipiana do episodismo ontológico.

Há outras consequências ligadas a esta tese de uma conexão mitigada que não posso desenvolver aqui, por falta de espaço. Limito-me a observar algo que esta doutrina não possui porque não a pode possuir: uma doutrina unificada da substância. O que há aqui são dois domínios distintos, mas conectados, todavia certamente não um domínio unificado da substância. Ora, o livro Z da Metafísica propõe-se justamente a fazer isso, uma doutrina unificada da substância: mediante o estudo da natureza da substância sensível, à qual se limita metodologicamente a investigação levada a termo naquele livro, ele pretende poder decidir sobre a possibilidade de uma substância de outra natureza, determinando em grandes linhas qual pode ser tal natureza (ver em especial Z 2 1028b27-32 e 17 1041a6-9). Não importa aqui determinar qual sucesso Aristóteles tem nessa nova empreitada, se sucesso alcança; o decisivo é que ele se engaja em uma outra perspectiva, fortemente distinta daquela que perseguia quando redigiu o tratado das Categorias e, presumivelmente, também o livro $\Lambda$ : não mais uma certa conexão, tênue em si mesma, mas forte o suficiente para espantar o espectro de uma ontologia dispersa em domínios desconectados principialmente, mas convivendo juntamente como cenas de uma má tragédia. Agora, no livro Z, se trata de buscar algo muito mais forte: uma doutrina unificada da substância.

Para concluir, gostaria de formular uma última questão: o que leva Aristóteles a buscar uma ontologia unificada da substância, deixando como que inacabado o projeto de uma ontologia regional da substância sensível sob a forma dos traços gerais da entidade? A resposta não é evidente e temos de lidar aqui somente com conjecturas mais ou menos plausíveis. A doutrina unificada da substância levada a termo no livro Z é aberta com a exposição, em Z 1, da unificação do ser em suas diferentes categorias mediante a doutrina da significação focal. Isso leva à 
substituição do problema do ser pela questão da substância, pois agora a substância é o ser primeiro, à qual todas as outras categorias remetem em suas definições. A passagem de uma insolúvel gigantomaquia em torno do ser a uma doutrina pacificada da substância a título não de ser único, mas somente de ser primeiro, é celebrada como uma correção de rumo fundamental em Z 1 1028b2-4, o que cria a expectativa de uma solução de conflitos que pareciam antes intratáveis. Dois passos são necessários e distintos, ainda que logicamente conexos. É preciso primeiro domesticar a dispersão do ser por meio de uma doutrina da substância. Feito isso, um segundo passo consiste em ver que itens compõem esta categoria que foi agora alçada a ser primeiro. ${ }^{29}$ Pode ser o caso que estes itens sejam vítimas de uma irrecuperável homonímia; afinal, quando olhamos a categoria da qualidade, vemos quatro grandes tipos que, ao que tudo indica, são irredutíveis entre si, constituindo portanto uma nova plêiade que permanece distinta entre seus membros. O mesmo poderia ocorrer com a substância: dois tipos básicos, porém desconectados. O livro Z, porém, parece encontrar na imaterialidade da forma um mecanismo para evitar tal episodismo, conectando de algum modo os dois tipos básicos de substância: a forma imaterial é sempre imanente nas substâncias sensíveis, mas nada impede que ocorra uma forma não somente separável ( $\chi \omega$ pıøtóv), mas ontologicamente separada ( $\varepsilon \chi \omega \rho ı \mu \varepsilon \dot{v} \eta)$ de todo elemento material ou potencial, precisamente o primeiro motor imóvel, causa última da eternidade ordenada do movimento, cuja possibilidade ontológica é assegurada pela investigação mesma da natureza da substância sensível e de sua forma imanente à matéria.

Parece plausível supor que, uma vez domesticada a dispersão originária do ser por meio da doutrina da significação focal, o interesse metafísico de Aristóteles deslocou-se em direção a uma doutrina unificada da substância, que ocupa agora o lugar privilegiado de ser primeiro. Esse novo interesse, por sua vez, parece ter deixado à sombra, como que inacabado, o projeto de descrever a entidade sensível por meio dos traços gerais do ser. Um sinal disso seria o fato que a expressão agora omnipresente é "o ser

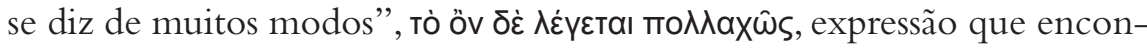
tramos por toda a obra de Aristóteles e que se tornou, legitimamente, o bordão de sua metafísica. Esta fórmula sintetiza a nova perspectiva de buscar na referência entre definições (portanto em seu reflexo na linguagem) 


\section{6}

o elo que une todas as categorias em torno de uma e mesma categoria, a categoria da substância. No entanto, cá e lá, encontramos vestígios daquela outra perspectiva. Assim, em $\Delta 11$, examinando as noções de anterior e posterior, ao mencionar a doutrina da anterioridade por natureza em um contexto platônico, Aristóteles subitamente escreve que, "visto que

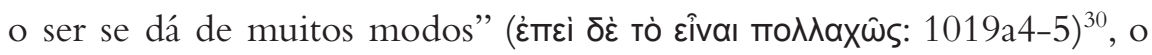
substrato é anterior e por isso a substância também é anterior - o que nos faz lembrar a doutrina das Categorias e sua prioridade à substância individual, que funciona como substrato de contrários (que era, como vimos, a característica própria da substância). ${ }^{31}$ De modo similar, Teofrasto escrevia, em sua Metafísica, que "é evidente que o ser se dá de muitos

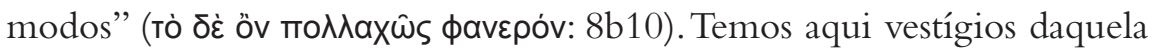
outra perspectiva: não é que o ser se diz de muitos modos, o ponto é que o ser se dá ou simplesmente é de muitos modos. Não há aqui a interface da linguagem, que faz com que todas as outras categorias contenham, em suas definições, uma referência à substância, que se alça deste modo a ser primeiro. Para aquela perspectiva, a refração definicional em nada serve para domesticar a dispersão do ser; é preciso antes classificar a entidade segundo seus traços mais básicos - ainda que o preço a pagar por isso seja a regionalização das ontologias, que posteriormente devem ser conectadas de algum modo, para que se evite a figura de uma ontologia episódica aos moldes de Espeusipo.

No Fédon 99d4-100a8, ao relatar a biografia intelectual de Sócrates, Platão o faz explicar como, tendo abandonado as esperanças de ir às coisas mesmas, como se pudesse olhar diretamente ao sol em um eclipse, preferiu as ver em seu reflexo, como os que olham para o eclipse por meio de sua imagem em um lago. Sócrates decidiu então refugiar-se nos enunciados, para neles buscar a verdade das coisas, fazendo deste modo "a segunda navegação em busca da causa" (99c9-d1), na qual a linguagem toma o lugar das coisas na condução da investigação sobre o ser. Em certo sentido, a mudança de perspectiva em Aristóteles que ora vimos é também a sua segunda navegação: a metafísica geral renasce das cinzas das ontologias regionais quando Aristóteles abandona o projeto de domesticar o ser mes-

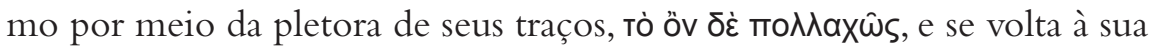


focal de significação de tudo o que é. 
${ }^{1}$ A história de sua colocação nesta posição inicial e da atribuição de seu título é bastante conturbada; ver, a esse respeito, a introdução feita por Richard Bodéüs, extremamente detalhada, à sua edição crítica das Categorias (Belles Lettres 2001, pp. xi-ccxviii). Sobre os catálogos antigos, ver P. Moraux, Les listes anciennes des ouvrages d'Aristote, Louvain 1951; O. Gigon, Aristotelis Opera vol. iii, De Gruyter 1987, pp. 19-45. Dispomos, em português, de uma excelente tradução, precedida de um lúcido ensaio: Ricardo Santos, Categorias, Porto 1995. Sobre a história das Categorias nos séculos seguintes, ver O. Bruun e L. Corti (eds.), Les Catégories et leur histoire, Vrin 2005.

${ }^{2}$ In cat. 56, 25-29: "não é para o ensino dos Tópicos que se deve primeiro aprender o que é relativo às categorias, mas também para o estudo dos Analíticos e das proposições categóricas, de fato em geral para todos os outros estudos, pois este livro é o mais básico e introdutório a todas as partes da filosofia".

${ }^{3}$ Ver em especial EnéadaVI 1. Plotino atribui a Aristóteles a tese que "o ser não é unívoco em todas as categorias" (VI 11 18-19); Porfírio consequentemente apresenta o ser em Aristóteles como homônimo (61, 10; ver também Dexipo, 13, 6).

${ }^{4}$ A passagem refere-se ao tratado das Categorias por meio do tema ali tratado.

${ }^{5}$ Para a Eisagôgê, ver a excelente tradução comentada de Jonathan Barnes, Porphyry Introduction, Oxford, 2003.

${ }^{6}$ Ver a este respeito P. Hoffmann, What was commentary in late antiquity?, in M.-L. Gill e P. Pellegrin (eds.), A companion to Ancient Philosophy, Blackwell, 2009, pp. 597-622. Um relato curioso da intensa atividade intelectual de Proclo se encontra em Marino (ver H. Saffrey e A.-P. Segonds, Marinus - Proclus ou sur le bonheur, Belles Lettres, 2002, \$22); uma tentativa de detalhamento do quotidiano de Proclo e seus discípulos é proposta por H. Saffrey em Proclus, diadoque de Platon (in H. Saffrey, Recherches sur le néoplatonisme après Plotin,Vrin, 1990, pp. 14158; sobre o programa de estudos, Saffrey escreve que "c'était d'abord Aristote pour préparer à Platon, c'est-à-dire les traités de logique et de philosophie naturelle. Ensuite c'étaient les dialogues de Platon, lus et expliqués dans un ordre pédagogique qui était en vigueur déjà dans l'école de Jamblique à Apamée de Syrie. La liste est la suivante: Premier Alcibiade, Gorgias, Phédon, Cratyle, Théétète, Sophiste, Politique, Phèdre, Banquet, Philèbe, et pour finir Timée et Parménide" < p. 150>). Simplício nos diz que, quanto à questão de decidir por onde começar o estudo de Aristóteles, havia duas respostas: uns diziam que devia ser pelos tratados do Órganon $(5,5)$; outros, pelos tratados éticos $(5,16)$. Simplício posiciona-se em favor dos primeiros; e, no que toca ao Órganon, argumenta que se deve começar pelo tratado das Categorias (15, 13-16).

${ }^{7}$ A. Trendelenburg, Geschichte der Kategorienlehre, Berlim, 1846 (Olms, 1979): A substância primeira, o indivíduo, não é predicado, mas estabelece a condição necessária para toda predicação, ao mesmo tempo em que a substância segunda - a espécie ou o gênero - se atribui a um sujeito a título de um predicado especial.T. Waitz mostrou-se simpático a esta posição: "grammaticis potissimum rationibus ductum Aristotelem divisionem categoriarum constituisse Trendelenburgius ostendit in Prolusione" (Aristotelis Organon graece, Leipzig, 1844, vol. I 268).

${ }^{8}$ Para a expressão, ver, na Metafísica, $\Delta 6$ 1016b34, 7 1017a23, 28 1024b13, E 2 1026a36, @ 10 1051a35, I 3 1054b29-30.

doispontos, Curitiba, São Carlos, vol. 10, n. 2, p.225-254, outubro, 2013 
${ }^{9}$ E. Benveniste, Catégories de pensée et catégories de langage, reproduzido em Problèmes de linguistique générale I, Paris, 1966, pp. 63-74. O débito como que inconsciente seria sobretudo visível nos exemplos usados por Aristóteles: assim, a categoria de estar em uma posição, exemplificada



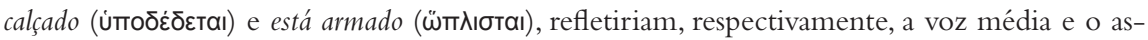
pecto permansivo do perfeito grego.

${ }^{10}$ Ver, em especial, Aristote et le langage, artigo em que Aubenque busca compreender as categorias de Aristóteles no "enracinement de la pensée dans un système linguistique toujours plus ou moins particularisé” (P. Aubenque, Problèmes aristotéliciens, Vrin, 2009, pp. 11-30, citação na pg. 13); ver também P. Aubenque (ed.), Concepts et catégories dans la pensée antique,Vrin, 1980.

${ }^{11}$ H. Bonitz, Ueber die Kategorien des Aristoteles, Wien, 1853 (Darmstadt, 1967); citação da pg.

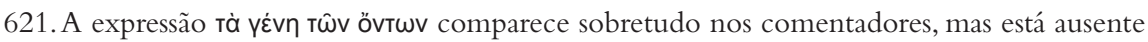
da Metafísica; no entanto, a encontramos em An. Post. I 32 e De anima II 1 412a6, referida, respectivamente, a qualidades e quantidades e à substância.

${ }^{12}$ F. Brentano, Von der mannigfachen Bedeutung des Seienden nach Aristoteles, Freiburg, 1862, especialmente capítulo V, pp. 72-82. A obra é dedicada a Trendelenburg.

13 E. Zeller, Die Philosophie der Griechen in ihrer Geschichtlichen Entwicklung, II 2 p. 259260: "diese obersten Begriffe oder Kategorien bezeichnen für ihn weder blos subjektive Denkformen, welche seinem Realismus von Hause aus fremd sind, noch überhaupt blos logischeVerhältnisse; es sind vielmehr die verschiedenen Bestimmungen des Wirklichen, welche sie ausdrücken" (6a. ed., Olms, 1963). A última edição revista por Zeller é a quinta, datada de 1892; a sexta (e definitiva) edição foi publicada postumamente em 1919, sob os cuidados de Franz Lortzing. Zeller adota a linha geral de Bonitz e Brentano contra a interpretação linguística de Trendelenburg, mas toma certa distância em relação à posição destes dois autores (ver em especial n. 2, p. 262-263). A enorme influência desta obra talvez explique por que Benveniste pensou estar inovando em sua tese, contrária à posição hegemônica em sua época, quando em boa parte renovava com a posição gramatical já exposta por Trendelenburg.

${ }^{14}$ Sobre este tratado, Bonitz escreve que "nusquam in hac disputatione alius libri mentio fit"

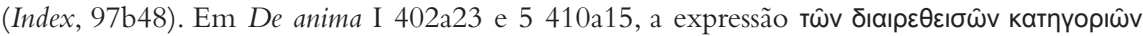
poderia ser tomada como uma remissão temática ao tratado das Categorias, mas o fato de a lista,

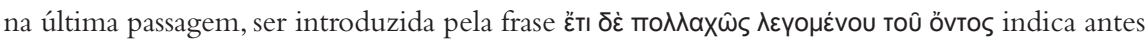
uma referência à doutrina das categorias tal como concebida após o tratado das Categorias;

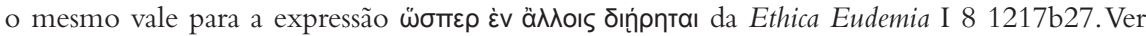
nota 30, mais adiante; sobre este ponto, ver também Carlo Natali, Struttura e organizzazione del trattado aristotelico detto Categorie, in M. Bonelli e F. Masi (eds.), Studi sulle Categorie di Aristotele, Amsterdam, 2011, pp. 17-30.

15 Ter é uma das categorias listadas no capítulo 4, mas seu tratamento, como veremos, diverge radicalmente do atribuído às categorias na seção (b); ademais, a interpolação em 11b10-17 diz que não é preciso analisá-la, visto ser evidente.

${ }^{16}$ S. Mansion, La première doctrine de la substance: la substance selon Aristote, in S. Mansion, Études aristotéliciennes, Louvain, 1984, pp. 303-369 (citação na pg. 301); ver também La doctrine aristotélicienne de la substance et le traité des Catégories, ibidem, pp. 305-308. A inautenticidade é igualmente

doispontos, Curitiba, São Carlos, vol. 10, n. 2, p.225-254, outubro, 2013 
proposta por Bertrand Dumoulin, L'ousia dans les Catégories et dans la Métaphysique, in P. Moraux e J.Wiesner (eds.), Zweifelhaftes im Corpus Aristotelicum, De Gruyter, 1983, pp. 57-72.

${ }^{17}$ M. Frede, Titel, Einheit und Echtheit der aristotelischen Kategorienschrift, que foi publicado originalmente em P. Moraux e J.Wiesner (eds.), Zweifelhaftes im Corpus Aristotelicum, De Gruyter, 1983, pp. 1-29 (versão em inglês: M. Frede, Essays in Ancient Philosophy, Minneapolis, 1987, pp. 11-28; ver também, nesta obra, Categories in Aristotle, pp. 29-48). Neste nono Symposium Aristotelicum, dedicado aos textos sob discussão de autenticidade, Andreas Graeser havia também acentuado a relação entre a reflexão desenvolvida no tratado das Categorias e a doutrina platônica (A. Graeser, Aspekte der Ontologie in der Kategorienschrift, ibidem, pp. 30-56). A proximidade com os Tópicos é bem exposta por Isaac Husik, On the Categories of Aristotle (Philosophical Review 13 1904, pp. 514-528); sobre este tema, ver também Kurt von Fritz, Der Ursprung der aristotelischen Kategorienlehre (Archiv für Geschichte der Philosophie 40, 1931, pp. 449-496).

18 Por definição deve-se entender aqui definição real; o estatuto da definição nominal (à qual Aristóteles faz menção nos Segundos Analíticos II) não entra em consideração aqui. Sobre o problema da definição, ver em especial D. Charles (ed.), Definition in Greek Philosophy, OUP, 2010.

19 O que não significa que a categoria da substância não se envolva com algum tipo de predicado, pois, ao admitir que a espécie e o gênero são substâncias (a título de substâncias segundas), Aristóteles - ou o autor deste tratado - deverá mostrar como esta categoria pode simultaneamente designar o sujeito e um tipo de predicado (a saber, os predicados que "deli-

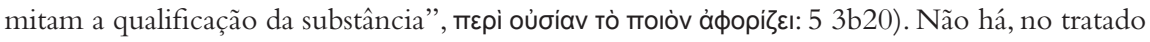
das Categorias, uma resposta clara a este problema; a substância segunda fica em um limbo entre a qualidade e a substância primeira, pois é uma qualidade, mas não qualquer qualidade (cf. 5 3b10-23).

${ }^{20}$ Doravante, deixarei de lado a seção (c), que inicia após as linhas intercaladas 11b10-17. Os capítulos da seção (c) não seguem mais a estrutura típica dos capítulos da seção (b). Mesmo no capítulo 15, que versa sobre a categoria do ter, listada no cap. 4, o tratamento é distinto, pois são unicamente mencionados os casos de ter, sem exame das características que todo item deve satisfazer para fazer parte desta categoria.

${ }^{21}$ Um exemplo disso é a acepção platônica de substância, apresentada em $\Delta 8$ 1017b17-21.

${ }^{22}$ Assim como a sensação (mencionada igualmente em 7 6b35-36). O tema da sensação e do conhecimento como relativos é discutido em PhysicaVII 3.

${ }^{23}$ Em 6b21-22 é dito que não somente o semelhante e o dessemelhante admitem graus, mas que também o admitem o igual e o não-igual. Isso parece ser um problema, pois igual e não-igual, como veremos a seguir, são a marca própria das quantidades e quantidades, diz expressamente o texto (6a25-35), não admitem graus. Há duas maneiras de resolver este problema. Pode-se propor que, nesta passagem, igual e não-igual referem-se propriamente a qualidades, como a de ser igualitário (justo) ou não-igualitário (injusto) e não a quantidades (esta é, por exemplo, a interpretação adotada por Bodéüs, em nota de sua tradução). Ou se interpreta igual e não-igual em sentido matemático estrito, mas se tomam as linhas seguintes, "nem todos relativos, porém, admitem mais ou menos, pois o duplo não é dito mais ou menos duplo, nem nenhum relativo deste tipo" (6b24-27) como corrigindo o que havia sido dito antes e que

doispontos, Curitiba, São Carlos, vol. 10, n. 2, p.225-254, outubro, 2013 
estaria reportando uma posição comum - rávta aqui teria como escopo o que foi introduzido expressamente em 6b21-23 (“todos estes relativos”), do qual são excluídas as quantidades relativas. A segunda interpretação parece-me preferível.

${ }^{24}$ O que, de quebra, explicaria por que a simultaneidade (Cat. 13) não encontra nenhum correspondente no livro $\Delta$ da Metafísica. Nesta linha, pode-se talvez também explicar o fato de tampouco haver no livro $\Delta$ um capítulo sobre a categoria do agir e sofrer (examinada no capítulo truncado 9 das Categorias): estas categorias foram inicialmente agrupadas para depois, aparentemente, serem retiradas da lista das categorias na Metafísica (se é que há uma tal lista final).

${ }^{25}$ Com base na estreita conexão entre as Categorias, os Tópicos e as Refutações Sofísticas, Stephen Menn buscou sustentar que nosso tratado é "an encheiridion for the dialectician to use in constructing arguments: the ultimate justification of the rules is simply their success"; ou ainda: "we can best make sense of the structure of the Categories, and of many of its particular points, if we regard it as a manual for testing terms proposed in dialectical argument" (S. Menn, Metaphysics, Dialetic and the Categories, in Revue de Métaphysique et de Morale, 100 1995, pp. 311337; citações em pp. 315 e 320, respectivamente). Richard Bodéüs, de modo mais comedido, acentuando também esta conexão, viu, porém, em nosso tratado, antes uma reflexão sobre as práticas com as quais o dialético está envolvido e que são descritas nos Tópicos, o que teria levado seu autor a se preocupar em especial com o estatuto da substância:"il semble donc qu'il faille résister à la tentation de placer notre traité parmi les présupposés des Topiques, qui ne s'y réferent d'ailleurs nulle part, et plutôt considérer que l'enseignement des Topiques a servi de point de départ à l'auteur des C < as Categorias >, pour amorcer un exposé original sur la substance" (Aristote - Catégories, Belles Lettres 2001, p. lxxix). Haveria assim uma aspiração menos rente à simples dialéctica. Menn permanece mais negativo: a respeito dos traços próprios, ele escreve que "these idia do not make sense as a contribution to studying being qua being, but only as a contribution to dialectic" (ibidem, p. 322).

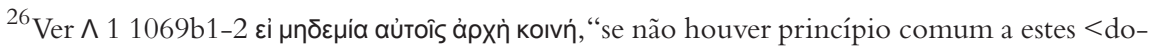
mínios>”. Não posso examinar aqui os problemas ligados a este condicional; assinalo somente que o livro $\Lambda$ visa a mostrar que o condicional não é satisfeito, pois há um princípio comum aos dois domínios. Para este ponto, ver em especial M. Frede, Metaphysics $\wedge 1$, in M. Frede e D. Charles (eds.), Aristotle's Metaphysics Lambda, Oxford 2000, pp. 53-80. Muito do que é dito aqui por mim é certamente controverso. A noção de independência está mencionada obliquamente por meio da afirmação que, não havendo princípio comum, a ciência que porta sobre a

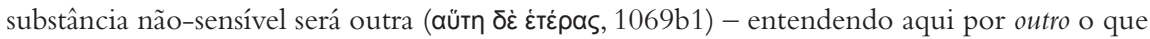
é inteiramente outro ou desconectado.

${ }^{27}$ A estas passagens se deve acrescentar Poética 9 1451b33-35, a propósito de uma má tragédia por estar articulada em episódios estanques. Sobre Espeusipo, ver M. Isnardi Parente, Speusippo - Frammenti, Bibliopolis 1980, especialmente pg. 274.

28 Sobre a Metafísica de Teofrasto, ver a edição de André Laks e Glenn Most, Théophraste Métaphysique, Belles Lettres 1993. Em minha opinião, as opções estão entre (a) uma desconexão principial e (b) algo que faz as vezes de uma conexão, estando excluída (c) uma fonte única dos dois domínios, capaz por isso mesmo de assegurar uma perfeita unidade. $\mathrm{O}$ valor de oîov deve, parece-me, acompanhar o sentido restritivo de tis em бuvaфń тıৎ (4a9-10) e tıva бuvaфǹv (4a13-14). Em sentido contrário, Laks e Most sustentam que as duas possibilidades 
seriam (a) uma colaboração forte entre os dois domínios, marcada por uma quase-comunidade (como traduzem oîov koıvwvia), e (b) uma simples justaposição, que é mesmo assim uma certa colaboração, o que é descartado de início sendo a hipótese (c) de uma total falta de relação principial (op. cit., p. 26).

${ }^{29}$ Sobre este tema, tomo a liberdade de remeter a um estudo meu, L'homonymie de l'être et le projet métaphysique d'Aristote, publicado na Revue Internationale de Philosophie 201 1997, pp. 333-356.

${ }^{30}$ Vestígio que é recoberto pelas traduções: "if we consider the various senses of 'being", segundo a Revised Oxford Translation (ed. Jonathan Barnes, Princeton 1984); "puesto que 'ser' se dice en varios sentidos”, na tradução de García Yebra (Metafísica, Gredos 1998); "prenons l'Etre dans ses diverses acceptions", segundo Tricot (Métaphysique, Vrin 1986); "puisque être se dit en plusieurs sens", na nova tradução francesa de M.-P. Duminil e Annick Jaulin (Aristote


Porém, já a recensio de Moerbeke trazia: "quoniam autem esse multipliciter". Christopher Kirwan também dá uma tradução mais rente ao texto: "since there are many ways of being" (Metaphysics Books Г, $\Delta$ and E, Clarendon Press 1993).

31 É bem conhecido que o tratado das Categorias não opera com a distinção forma - matéria, mas não deixa por isso de tomar o indivíduo, a substância primeira, como o substrato para tudo o mais (pois o restante ou é dito do indivíduo, no caso das substâncias segundas, ou inere a ele, no caso das demais categorias: 5 2b3-6c); neste sentido, é afirmado, logo adiante, que "as substâncias primeiras são ditas substâncias no mais genuíno sentido por servirem de substrato

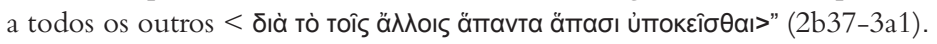

\section{Referências bibliográficas}

AUBENQUE, P. 2009. Aristote et le langage. In: . Problèmes aristotéliciens, Paris:Vrin.

(ed.). 1980. Concepts et catégories dans la pensée antique. Paris:Vrin.

BARNES, J. (ed.). 1984. The complete works of Aristotle - The revised oxford translation. Princeton, Princeton University Press. 2003. Porphyry - Introduction. Oxford: Oxford U. P.

BENVENISTE, E. 1966. Catégories de pensée et catégories de langage. In:__ Problèmes de linguistique générale I. Paris: Gallimard.

BODÉÜS, R. 2001. Aristote - Catégories. Paris: Belles Lettres.

BONITZ, H. [1853] 1967. Ueber die Kategorien des Aristoteles. Darmstadt: Wissenschaftliche Buchgesellschaft. 
BRENTANO, F. [1862] 1963. Von der mannigfachen Bedeutung des Seienden nach Aristoteles. 6 ed. Hildesheim: Olms.

BRUNN, O.; CORTI, L. (eds.) 2005. Les Catégories et leur histoire. Paris: Vrin.

BUSSE, A. 1887. Porphyrii Isagoge et In Aristotelis Categorias Commentarii. Berlin: Georg Reimer. 1888. Dexippi In Aristotelis Categorias Commentarium. Berlin:Typis et Impensis Georg Reimer.

BYWATER, I. (ed.) 1894. Aristotelis - Ethica Nicomachea. Oxford: Oxford U.P.

CHARLES, D. (ed.) 2010. Definition in Greek Philosophy. Oxford: Oxford U.P.

DUMOULIN, B. 1983. L'ousia dans les Catégories et das la Métaphysique. In MORAUX, P.; WIESNER, J. (eds.) Zweifelhaftes im Corpus Aristotelicum. Berlin: De Gruyter.

FREDE, M. 1983. Titel, Einheit und Echtheit der aristotelischen Kategorienschrift. In MORAUX, P.; WIESNER, J. (eds.) Zweifelhaftes im Corpus Aristotelicum. Berlin: De Gruyter.Versão inglesa publicada em FREDE, M. 1987. Essays in Ancient Philosophy. Minneapolis: University of Minnesota Press.

1987. Categories in Aristotle. In: . Essays in Ancient

Philosophy. Minneapolis: University of Minnesota Press. . 2000. Metaphysics $\wedge$ 1. In FREDE, M.; CHARLES, D. (eds.) Aristotle's Metaphysics Lambda. Oxford: Oxford U. P.

FRITZ, K. 1931. Der Ursprung der aristotelischen Kategorienlehre. Archiv für Geschichte der Philosophie 40, pp. 449-496.

GIGON, O. 1987. Aristotelis Opera vol. III. Berlin: De Gruyter.

GRAESER, A. 1983. Aspekte der Ontologie in der Kategorienschrift. In MORAUX, P.; WIESNER, J. (eds.) Zweifelhaftes im Corpus Aristotelicum. Berlin: De Gruyter. 
HOFFMANN, P. 2009. What was commentary in late antiquity? In. GILL, M. L.; PELLEGRIN, P. (eds.) A companion to Ancient Philosophy, Blackwell.

HUSIK, I. 1904. On the Categories of Aristotle. Philosophical Review 13, pp. 514-528.

JAEGER, W. (ed.) 1957. Aristotelis - Metaphysica. Oxford: Oxford U. P.

KALBFLEISH, C. 1907. Simplicii In Aristotelis Categorias Commentarium. Berlin: Georg Reimer.

KASSEL, R. (ed.) 1965. Aristotelis - De Arte Poetica Liber. Oxford: Oxford U. P.

LAKS, A.; MOST, G. 1993. Théophraste - Métaphysique. Paris: Belles Lettres.

MANSION, S. 1984. La première doctrine de la substance: la substance selon Aristote. In . Études aristotéliciennes. Louvain: Éditions de l'Institut supérieur de philosophie.

. 1984. La doctrine aristotélicienne de la substance et le traité des Catégories. In __. Études aristotéliciennes. Louvain: Éditions de l'Institut supérieur de philosophie.

MENN, S. 1995. Metaphysics, Dialetic and the Categories. Revue de Métaphysique et de Morale, 100 1995, pp. 311-337.

MINIO-PALUELLO, L. (ed.) 1949. Aristotelis - Categoriae et Liber de Interpretatione. Oxford: Oxford U. P.

MORAUX, P. 1951. Les listes anciennes des ouvrages d'Aristote, Louvain: Éditions de l'Institut supérieur de philosophie.

PARENTE, I. 1980. Speusippo - Frammenti. Napoli: Bibliopolis. ROSS, D. (ed.) 1951. Aristotelis - Physica. Oxford: Oxford U. P. . (ed.) 1956 Aristotelis - De Anima. Oxford: Oxford U. P. . (ed.) 1958. Aristotelis - Topica et Sophistici Elenchi. Oxford: Oxford U.P. 
. FOBES, F. H. (eds.) 1929. Theophrastus - Metaphysics. Chicago:

Ares.

MINIO-PALUELLO, L. (eds.) 1981. Aristotelis - Analytica Priora et Posteriora. Oxford: Oxford U. P.

SAFFREY, H. 1990. Proclus, diadoque de Platon. In Recherches sur le néoplatonisme après Plotin. Paris:Vrin.

SEGONDS, A. P. 2002. Marinus - Proclus ou sur le bonheur. Paris: Belles Lettres.

SANTOS, R. 1995. Categorias. Porto: Porto Editora.

SCHWYZER, H. R.; HENRY, P. (eds.) 1964-1984. Plotini Opera.

Oxford, Oxford U. P.

TRENDELENBUR G, A. [1846] 1979. Geschichte der Kategorienlehre. Hildesheim: Olms.

WAITZ, T. 1844. Aristotelis Organon graece. Leipzig: Sumtibus Hahnii.

ZELLER, E. [1844] 1963. Die Philosophie der Griechen in ihrer geschichtlichen Entwicklung. 6 ed. Hildesheim: Olms.

ZINGANO, M. 1997. L'homonymie de l'être et le projet métaphysique d'Aristote. Revue Internationale de Philosophie,Vol. 51, n. 20, pp. 333-356. 